\title{
Establishment of a Belt and Road Dispute Settlement Mechanism
}

\section{Weidong $\mathrm{Zhu}^{*}$}

Considering the large number of civil, commercial and investment disputes that arise between Chinese investors and their counterparts along the Belt and Road, it is necessary to establish a dispute settlement mechanism. The open, cooperative and non-institutionalized features of the Belt and Road Initiative require the reform and improvement of China's domestic dispute settlement mechanism for foreign civil, commercial and investment disputes; and bilateral and multilateral dispute settlement mechanisms between or among China and the Belt and Road countries should be strengthened. When appropriate, China may propose the establishment of a multilateral dispute settlement mechanism that is especially designed for the Initiative. The status quo of dispute settlement mechanisms between China and the Belt and Road countries necessitates the establishment of a preset mechanism that uses arbitration as the primary approach, litigation as the secondary approach, and mediation as an alternative.

Keywords: BRI, Dispute Settlement Mechanism, Multiple, Litigation, Arbitration, Mediation

* Senior Research Fellow at the Institute of West Asian and African Studies of the Chinese Academy of Social Sciences. LL.M. (Xiangtan Univ.), Ph.D. (Wuhan), Post-Doc. (Cantab). ORCID: https://orcid.org/0000-0002-1069-7636. The author may be contacted at: zhuwd@cass.org.cn/ Address: Mailbox 1120, No.3, Zhang Zizhong Road, Dongcheng District, Beijing, China. 


\section{INTRODUCTION}

Since 2013, the implementation of the Belt and Road Initiative ("BRI") has aroused much attention. However, legal disputes that have arisen among the Belt and Road ("BR") countries have also attracted the great attention of Chinese legal circles. Some legal scholars have put forward various designs for a BR dispute settlement mechanism. ${ }^{1}$ Meanwhile, top Chinese officials have attached great importance to the establishment of a BR dispute settlement mechanism.

On January 23, 2018, the Central Leading Team for Comprehensively Deepening Reform in China adopted the "Opinions on Establishing a Dispute Resolution Mechanism and Institution for the Belt and Road,"2 which set guidelines for the establishment of a BR dispute settlement mechanism. Subsequently, at the end of June, 2018, the Supreme People's Court in China set up the First International Commercial Tribunal in Shenzen and the Second International Commercial Tribunal in Xi' an. It also promulgated the Supreme People's Court's Provisions on the Establishment of the Belt and Road Dispute Settlement Mechanism and Institutions, which made stipulations about such matters as jurisdiction, choice of law, proof of foreign law, etc. ${ }^{3}$ These efforts represent an important step toward building a BR dispute settlement mechanism.

The primary purpose of this research is to search for the way of establishing a comprehensive dispute settlement mechanism for BRI. In this article, the author first explores the necessity of a BR dispute settlement mechanism, then analyzes the two elements that should be taken into account. Finally based on this analysis, he examines ways to build a comprehensive BR dispute settlement mechanism.

\section{The Necessity for the Establishment of a BR Dispute Settlement Mechanism}

The BRI has been widely recognized across the world since its proposal by Chinese President Xi Jinping in 2013. ${ }^{4}$ By the end of 2017, the BRI had been included in various resolutions or documents adopted by the UN General Assembly, the UN Security Council and other international institutions. ${ }^{5}$ China has concluded over 150 BRI Cooperation Agreements with nearly 140 countries 
and international organizations. Trade and investment between China and the BR countries have witnessed a great increase since the implementation of the BRI. For example, by the end of June, 2018, the trade volume between China and BR countries in reached over USD5 trillion, with an annual increase of 1.1 percent; the China's foreign direct investment ("FDI") to BR countries exceeded USD70 billion, with an annual increase of 7.2 percent; and the volume of newly concluded contracted projects by Chinese enterprises in the BR countries in was more than USD500 billion, with an annual increase of 19.2 percent. $^{6}$

However, China faces great political and legal risks when doing business with the BR countries, due to the potential political turbulence, frequent terrorist activities, poor legal systems and corrupt judicial environments that exist in some BR countries. According to the Report of the Risk Evaluation of the Chinese FDI (2016), ${ }^{7}$ most BR countries are of medium or high level risk. This may be also evidenced from the findings of Dorng Business (2018) published by the World Bank in October 2017. ${ }^{8}$ In terms of the "Ease of Doing Business Rankings," most BR countries rank very low, with the exception of certain developed countries located along the BR. ${ }^{9}$ A country's business environment is evaluated mostly on the Doing Business laws and regulations. Doing Business (2018) listed the following 11 areas as measuring factors: starting a business, dealing with construction permits, getting electricity, registering property, getting credit, protecting minority investors, paying taxes, trading across-borders, enforcing contracts, resolving insolvency and the labor market regulations. The results of the Doing Business (2018) guide showed that the majority of BR countries do not have the advanced legal framework for a sound and favorable business environment. ${ }^{10}$

The political and legal risks that exist in some BR countries have caused much damage and loss for Chinese businesses. Chinese investment projects in the past few years in some BR countries, for example, Myanmar, Mongolia, Sri Lanka, Mexico, Venezuela, and Poland, have been reportedly suspended or terminated due to environment, legal issues or political reasons. ${ }^{11}$ In such circumstances, it is rare and difficult for Chinese businesses to recover the time and money they invested in the projects. Even for Chinese investment projects that are underway in some BR countries, investment losses and legal disputes are very common as a result of political or legal problems. For example, the war in Libya in 2011 
interrupted nearly 50 investment projects carried out by 75 Chinese enterprises, with total losses of approximately USD 20 billion. ${ }^{12}$ Some of the investment disputes between Chinese businesses and host countries along the BR have been submitted to the ICSID or other international arbitral institutions. Examples include investment disputes between China Ping An Insurance Company and the government of Belgium, ${ }^{13}$ between the Beijing Urban Construction Group and the government of Yemen, ${ }^{14}$ and between the China Heilongjiang International Economic \& Technological Cooperative Co. et al. and the government of Mongolia. ${ }^{15}$

The BRI aims to establish policy coordination, infrastructure connectivity, unimpeded trade, finance integration and people to people exchange, which should result in more frequent cross-border civil and commercial transactions. In this regard, the establishment of a BR dispute settlement mechanism will help resolve various foreign-related civil and commercial disputes. The speedy and efficient settlement of such disputes requires a comprehensive dispute settlement mechanism; otherwise, the rights and interests of the participants in cross-border transactions will not be guaranteed. Accordingly, the cross-border movement of goods, service, capital and persons are often obstructed, which frustrates the expectations of the BRI. Indeed, according to data collected from the website of Chinese court judgments, ${ }^{16}$ the number of civil and commercial cases in the Chinese courts that involve parties from the other BR countries is largely increasing. The parties involved in these cases are from almost all of the countries along the BR. As mentioned above, investment disputes between Chinese businesses and the governments of the BR countries are also increasing in recent.

\section{Two Starting Points for Establishing a BR Dispute Settlement Mechanism}

The establishment of any dispute settlement mechanism must take into account certain relevant elements, such as legal traditions, legal culture, the nature of dispute, and the categories of the parties involved. This paper will mainly focus on two kinds of legal disputes between Chinese parties and those from the other 
BR countries; namely, (1) private foreign-related civil and commercial disputes (private international law cases) and (2) investment disputes, including investorstate investment disputes.

In designing a dispute settlement mechanism, two elements will be starting points. The one is the features of the BRI, and the other, the status quo of the legal framework in private international law matters and investor-state investment disputes among BR countries. The features of BRI will determine the uniqueness of the BR dispute settlement mechanism proposed in this work and help to determine how to establish such a mechanism. The status quo of the legal framework will demonstrate the acceptance of different dispute resolutions among the BR countries and help to determine the appropriate role and status of different dispute resolutions in terms of the proposed BR dispute settlement mechanism.

\section{A. The Features of the BRI}

With reference to the terms of the Vision and Action on Jointly Building the Silk Road Economic Belt and Twenty-first Century Maritime Silk Road (hereinafter Vision and Action) ${ }^{17}$ and the speeches on the BRI delivered by Chinese top officials on different occasions, the BRI's main features may be summarized as being open, cooperative and non-institutionalized.

First, the BRI is open to all countries who are interested in it. It is not confined to particular countries or regions. President Xi Jinping has mentioned the BRI's openness many times in his speeches. As he has pointed out, the BRI is not closed, but open and inclusive; it is not solely for China, but rather includes a true chorus comprising all BR countries; all countries, whether from Europe, Asia, America or Africa, may join the BRI. ${ }^{18}$ In the Joint Communiqué of the Leaders' Round Table of the Belt and Road Forum for International Cooperation (hereinafter Joint Communique) published on May 15, 2017, all leaders that attended the summit "welcome[d] and support[ed] the Belt and Road Initiative to enhance connectivity between Asia and Europe, which is also open to other regions such as Africa and South America." ${ }^{19}$ In fact, countries that have concluded BRI cooperation documents with China are not confined to countries along the $\mathrm{BR}$, but from various regions.

Second, the BRI is based on policy coordination with other countries for the 
purpose of achieving common development and building a shared future for all people in the countries concerned. 'Cooperation' was the most frequently used word in President Xi Jinping's speeches during the Belt and Road Forum for International Cooperation. ${ }^{20}$ The Joint Communiqué also expressed the intention to strengthen cooperation "on the basis of extensive consultation and the rule of law, joint efforts, shared benefits and equal opportunities for all." ${ }^{21}$ The Vision and Action plan shows that cooperation mechanisms are built up by the BR countries through bilateral and multilateral agreements. ${ }^{22}$

Lastly, the BRI is non-institutionalized. Currently, there is no established institutional framework or organizational arrangement. ${ }^{23}$ As the BRI is noninstitutionalized, 'cooperation' will be a better choice. The non-institutionalized arrangement of the BRI represents a 'restrained idea.' In terms of cost-efficient, it is thus reasonable to "make improvement under the existing legal frameworks" instead of "setting up new institutions or negotiating new arrangements."

A BRI dispute settlement mechanism cannot be established without taking the above three main features of the BRI into account. The openness of the BRI means that all countries may be potential partners of the BRI. Therefore, disputes between the BR countries may occur between Chinese parties and others from all over the world. Under such circumstances, if the settlement mechanism of foreign-related civil and commercial disputes, as well as of investment disputes in China, are improved, China may be an ideal location to settle their disputes between the BR countries. Given that the BRI is cooperative and noninstitutionalized, however, China needs to negotiate and conclude more bilateral or multilateral judicial assistance treaties or investment treaties with other BR countries. Of course, if the BRI can turn into an institutionalized framework, for example, in the form of an Economic Partner Agreement, a unified multilateral dispute settlement mechanism for the BRI may be established in the future. If the BRI remains open to all countries in the world, however, such a unified multilateral dispute settlement mechanism will be difficult, if not impossible, to establish.

\section{B. Status quo of the Dispute Settlement Legal Framework among the BR Countries}

As mentioned above, there is currently no specific institutional arrangement or 
institutionalized platform between China and the other BR countries to deal with civil, commercial and investment disputes. Therefore, such disputes must be dealt with through the existing national, bilateral and multilateral legal framework that the BR countries have made, concluded or acceded to. Upon examining the status quo of the existing dispute settlement legal framework among the BR countries, the acceptance of, and attitude toward various dispute resolution methods, including litigation, arbitration and mediation, among the BR countries may be demonstrated. For this analysis, I have examine 65 countries (including China), ${ }^{25}$ along the $\mathrm{BR}$ as examples to determine the existing state of civil and commercial dispute settlement mechanisms between China and the other BR countries.

Foreign-related civil and commercial disputes are settled mainly through litigation and arbitration. The two most important multilateral conventions concerning cross-border litigation are the Convention of 15 November 1965 on the Service Abroad of Judicial and Extrajudicial Documents in Civil or Commercial Matters (hereinafter Hague Convention on Service Abroad) and the Convention of 18 March 1970 on the Taking Evidence Abroad in Civil or Commercial Matters (hereinafter Hague Convention on Taking Evidence Abroad). As for a multilateral convention on the arbitration, there exists the 1958 New York Convention on the Recognition and Enforcement of Foreign Arbitral Awards (hereinafter New York Convention of 1958). As of May 18, 2018, among the 64 BR countries (excluding China), 30 countries are parties to the Hague Convention on Service Abroad; ${ }^{26} 29$ countries are parties to the Hague Convention on Taking Evidence Abroad; ${ }^{27} 61$ countries are parties to the New York Convention of $1958 ;^{28}$ and 52 BR countries are members of the 1965 Washington Convention on the Settlement of Investment Disputes Between States and Nationals from Other States (hereinafter 1965 Washington Convention). ${ }^{29}$ China is a party to each of these four multilateral conventions. Additionally, among the other 64 BR countries, 40 countries enacted arbitration laws based on the UNCITRAL Model Law on International Commercial Arbitration (hereinafter UNCITRAL Model Law). ${ }^{30}$ The adoption of the UNCITRAL Model Law is an important indicator in judging whether a country has advanced arbitration legislation. Because the arbitration laws in most of the BR countries are very modern, it can not only create an arbitration-friendly environment, but also help foreign parties to make use of these laws in disputes. 
As for bilateral arrangements that deal with civil and commercial disputes between China and the other BR countries, so far, among the other 64 BR countries, only seven countries ${ }^{31}$ have concluded bilateral treaties with China on judicial assistance in civil and commercial matters, and only 17 countries $^{32}$ have concluded bilateral treaties on judicial assistance in civil and criminal matters with China. These bilateral treaties contain provisions related to: (1) the service abroad of judicial and extrajudicial documents in civil and commercial matters; (2) the taking of evidence abroad; (3) the recognition and enforcement of arbitral awards and judgments; and (4) the exchange of legal information.

Given the diversified legal systems that exist among the BR countries, it is important to make such arrangements in bilateral treaties. However, the scope and provisions of these judicial assistance treaties are quite different, which may create barriers for the smooth settlement of foreign-related civil and commercial disputes between China and the other BR countries. For example, the judicial assistance treaties between China and Bulgaria, and between China and Kuwait, cover service abroad, taking evidence abroad, and recognition and enforcement of foreign judgments, and arbitral awards. Meanwhile, the judicial assistance treaty between China and Saudi Arabia excludes the recognition and enforcement of foreign arbitral awards, and the judicial assistance treaties between China and Thailand and China and Singapore address only the recognition and enforcement of foreign arbitral awards. Even in this case, however, the recognition and enforcement of foreign judgments are not included. In determining whether the foreign court rendering judgments has jurisdiction or not, the judicial assistance treaties between China and Saudi Arabia and between China and Kuwait provide a set of clear jurisdictional rules, while the other treaties make no such stipulations, leaving the question to be determined in light of the domestic laws of the country in which the judgment is made, or of the country in which such recognition and enforcement is sought.

With regard to investment disputes between parties from China and the other BR countries, 54 countries along the BR have concluded bilateral investment treaties ("BITs") with China. ${ }^{33}$ In the 54 BITs, 32 BITs provide that a dispute arising from the amount of compensation for expropriation or nationalization should be submitted to ad hoc arbitration, ${ }^{34}$ while only six BITs provide that such disputes may be submitted to the ICSID. ${ }^{35}$ For all investment disputes or relevant 
investment disputes, only 8 BITs accept ad hoc arbitration, ${ }^{36}$ and only 9 BITs accept the ICSID arbitration. ${ }^{37}$ Furthermore, in the 54 BITS, 40 BITs provide a pre-set amicable consultation procedure before resorting to arbitration or litigation. Obviously, all the BR countries would emphasize the role of amicable methods for dispute settlement, such as arbitration, consultation, and mediation. Nevertheless, the acceptance ration of the ICSID investor-state arbitration is very low among the BR countries.

As discussed above, there is a limited number of bilateral and multilateral treaties on judicial assistance in civil or commercial matters that China and other BR countries have concluded or to which they have acceded. These few treaties cover only a narrow range of the BR countries. For the arbitration, China and most of other BR countries are the parties to the New York Convention of 1958. They have also concluded many bilateral investment treaties, which provide for an arbitration mechanism to settle investment disputes. Many countries along the BR have modern and almost uniform arbitration laws based on the UNCITRAL Model Law. These provide favorable conditions for settling civil and commercial disputes between China and other BR countries through arbitration.

The 65 BR countries including China have different languages and national legal systems, ranging from common law to civil law and Islamic law. There are also some mixed jurisdictions in which different laws are applied simultaneously. For example, common law, customary law and Islamic law are applied in India. Common law, civil law and customary law are applied in Thailand and Nepal. Common law and Islamic law are applied in Pakistan and Bangladesh. These diversified legal systems and languages in the BR countries make it very difficult, if not impossible, for Chinese parties involved in civil, commercial and investment transactions with the BR countries to understand their national laws in such countries. The settlement of such disputes arising from the national legal mechanisms of the BR countries will result in many questions that are difficult to answer, such as the ascertainment of the jurisdiction, the proof of foreign laws, the service abroad of judicial documents, the taking of evidence abroad, the recognition and enforcement of foreign arbitral awards and judgments, and the translation of legal documents.

From the above analysis of the national, bilateral and multilateral dispute settlement mechanisms of civil, commercial and investment matters among the 
BR countries, this paper argues that arbitration is the optimal methods to settle disputes between or among the BR countries. By resorting to arbitration, the parties to the disputes may choose the language, the seat of the arbitration, and even the rules applicable to the arbitration proceedings. This may help prevent certain difficulties and embarrassment that foreign litigation would face. The judiciaries in China and some of the other BR countries have recognized the role and importance of arbitration or mediation in settling civil and commercial disputes. For example, the Suzhou Consensus reached at the Conference of the Presidents of the Supreme Courts of China and Central and Eastern European Countries held on May 5, 2016 clarified:

All of the parties present "recognize[d] the value of ADR mechanisms, such as mediation and arbitration that may provide efficient and expedient approaches to dispute resolution. The Supreme People's Court has been emphasizing the application of mediation to settle disputes, and the supreme courts of the Central and Eastern European countries will actively consider applying mediation and other ADR mechanisms in their respective countries. ${ }^{38}$

\section{Ways to Establish a BR Dispute SetTlement Mechanism}

A BR dispute settlement mechanism should be improving China's legal platform for settling foreign-related civil, commercial and investment disputes. This makes China an ideal choice for the parties involved to settle their disputes. In this course, China should negotiate and conclude more bilateral treaties with other BR countries or regional organizations to assure the smooth settlement of civil, commercial and investment disputes within the BR countries. Lastly, if possible, China may propose a unified multilateral dispute settlement mechanism to be agreed upon by all the BR countries. On the other hand, considering the status and acceptance of litigation, arbitration, and mediation among the BR countries, when designing a BR dispute settlement mechanism, arbitration should be considered the primary method, with litigation as a secondary method, and mediation as a preset procedure before either arbitration or litigation occur. 


\section{A. The Improvement of China's Foreign-related Civil, Commercial and Investment Dispute Settlement Mechanism}

Arbitration and litigation are the two main methods of resolution for foreignrelated civil and commercial disputes in China. However, as the deficiencies in China's Civil Procedure Law and Arbitration Law would have some negative effects on the smooth settlement of such disputes, these Laws need to be improved in the future. First, China may consider revising its 1994 Arbitration Law, especially repealing Article 16 concerning the validity of arbitration agreements. Article 16 stipulates that the parties must designate an arbitral institution in the arbitration agreement for the arbitration results to be valid. In accordance with Article 16, many foreign-related arbitration agreements have been and will be held invalid by Chinese courts because the arbitral institution is neither designated nor certain. In this situation, the foreign parties do not expect to settle their disputes through arbitration. Following Article 16 of the Chinese Arbitration Law, it would be better for the parties involved in the cross-border transactions not to choose China as the seat of their arbitration, and/or not to choose Chinese law as the lex causae of the arbitration agreement. ${ }^{39}$ Neither of these situations will have a positive impact on the development of arbitration in China. To create an arbitration-friendly environment and attract parties from the BR countries to choose to arbitrate their disputes in China, it is necessary to amend the Chinese Arbitration Law.

Taking into account the important role of arbitration in investor-state investment disputes, the Supreme People's Court should revise Article 2 of its Notice on Implementing the 1958 New York Convention to which China has acceded. ${ }^{40}$ It provides that investor-state disputes are not included in the disputes arising from contractual or non-contractual business legal relations, so that arbitral awards made in investor-state investment disputes may also be recognized and enforced under the 1958 New York Convention. ${ }^{41}$

As regard the settlement of civil and commercial disputes through litigation, the author would propose that China first consider improving provisions relating to such important areas as the jurisdiction over cross-border disputes, the service and taking of evidence abroad, and the recognition and enforcement of foreign judgments in domestic legislation. Let's take jurisdictional rules and recognition and enforcement rules as examples. The Judicial Interpretation issued 
by the Supreme People's Court of China on the Civil Procedural Law in 2015 (hereinafter Judicial Interpretation 2015), ${ }^{42}$ which serves as a kind of legislation, expressly adopted the doctrine of forum non conveniens and parallel litigation. This has been helpful to resolving jurisdictional conflicts between China and the other BR countries. However, the Judicial Interpretation 2015 only recognizes contradictory parallel litigation in which one of the parties institutes litigation in one country and the other party institutes litigation over the same subject matter in another country. ${ }^{43}$ It does not recognize repetitive parallel litigation in which the same party institutes litigation in two countries over the same subject matter, which impedes the ability of Chinese parties to settle disputes arising from the $\mathrm{BR}$ region through litigation in the Chinese courts. ${ }^{44}$

In practice, it is very common that one Chinese party brings litigation in a foreign court against another Chinese party over disputes arising locally. Due to delays in the foreign courts, however, the Chinese plaintiff in the foreign court will bring litigation again in a Chinese court against the same defendant over the same subject matter. If the Chinese court is not accepting such a disputes, in accordance with the provision of the Judicial Interpretation, the Chinese plaintiff in the foreign litigation will not get a timely remedy. In some circumstances, it will be more beneficial for both Chinese parties to settle their disputes which involve no other third party arising in the BR countries through litigation in the Chinese courts, especially when both Chinese parties are unwilling to litigate in the local courts along the BR. Therefore, the Supreme People's Court may issue another judicial interpretation that recognizes repetitive parallel litigation between Chinese parties when certain requirements are met, for example, when there is undue delay or manifest unfairness in the foreign court.

Recognition and enforcement of foreign judgments is another area worthy of attention in China. It will continue to constitute a great obstacle for the free movement of goods, capital, service and labor between China and other BR countries until the legislation and practice in this area is improved or changed. In the absence of mutual judicial assistance treaties regarding the recognition and enforcement of foreign judgments, the Chinese courts will strictly adhere to the doctrine of factual reciprocity, in terms of which Chinese court will examine whether there is a precedent indicating reciprocity. ${ }^{45}$ In other words, the Chinese courts will ascertain whether there are prior cases in which a foreign court has 
recognized or enforced the Chinese judgment. If yes, then there is reciprocity between China and the said country, so that the judgments from the foreign court will be recognized or enforced in China on the basis of such reciprocity. This will lead to the classic 'prisoner's dilemma' in the recognition and enforcement of foreign judgments.

The situation between China and Japan may be an illustrative example here. ${ }^{46}$ To break such a dilemma, China might adopt the doctrine of presumed reciprocity; namely, where there is great similarity in, or no manifest deviation from, provisions on the recognition and enforcement of foreign judgments between one country in which a judgment is made and the other in which the recognition and enforcement is sought, reciprocity is presumed to exist and the application may be upheld. For the wider and easier circulation of the judgments, this paper would propose that even a negative reciprocity might be adopted in China. Namely, the Chinese courts could first recognize and then enforce the foreign court's judgment on the basis of presumed reciprocity, unless the foreign judgments are found to be prejudicial to the fundamental principles of Chinese laws, to either China's sovereignty and security, or basic social interests in China, as stipulated in Chinese Civil Procedural Law. If a foreign court later denies the recognition and enforcement of Chinese judgments, then the presumed reciprocity would not be considered to exist between the two sides. ${ }^{47}$

In order to provide references and guidance for Chinese courts in dealing with cases arising from other BR countries, the Supreme People's Court published two sets of guidelines in July 2015 and May 2017, respectively. The 18 representative guiding cases selected are mainly those with foreign elements involving the BR countries. Subject matter involved includes the determination of the validity of arbitration agreements; the application of international treaties and international customs; the proof and application of foreign laws, public policy, and letters of credit; the contract of the carriage of goods by sea; the recognition and enforcement of foreign arbitral awards, etc. The foreign parties in these cases come from a wide range of the BR countries, including Singapore, Portugal, Malaysia, Poland, Germany, and Luxembourg. China is a basically civil law country, but these guiding cases are not fully followed as stare decisis. Their adjudications may thus be a guiding light for lower courts in China not to deviate so much when dealing with similar cases from the BR 
countries, so that parties in similar circumstances may be treated equally.

At the end of June 2018, the Supreme People's Court set up the First and the Second International Commercial Courts in Shenzhen and Xi'an, respectively. ${ }^{48}$ It has been the most important step to date in improving the dispute settlement mechanisms of foreign-related civil and commercial cases in China. Pursuant to the Supreme People's Court's Provisions on the Establishment of the Belt and Road Dispute Settlement Mechanism and Institutions, such international commercial courts will help the parties along the BR resolve their disputes through litigation, arbitration and mediation. ${ }^{49}$ The International Commercial Courts will have jurisdiction over five categories of international commercial disputes when: ${ }^{50}$ a) the parties choose to litigate in the Supreme People's Court by agreement in accordance with Article 34 of the Chinese Civil Procedure Law (the amount in question in these cases must exceed RMB300 million); ${ }^{51}$ b) the disputes originate within the jurisdiction of the Higher People's Court, but which should be heard by the Supreme People's Court by agreement; c) the disputes have a significant impact nationwide; d) the disputes apply for interim measures to assist with arbitration, for setting aside or enforcing arbitral awards in light of Article 14 of the Provisions; and e) the Supreme People's Court agrees that it should be heard by the International Commercial Court.

In order to provide a one-stop dispute settlement mechanism, the Supreme People's Court will form an international commercial law expert committee and select appropriate international mediation institutions and international commercial arbitral institutions to provide mediation and arbitration services to the parties. ${ }^{52}$

However, the International Commercial Courts will only adjudicate international civil and commercial disputes between equal parties. Therefore, state-state trade or investment disputes or investor-state disputes are not within the jurisdiction of these two courts. For international civil and commercial disputes or foreign-related civil and commercial disputes, China needs to conclude more bilateral judicial assistance treaties in civil and commercial matters with other BR countries, apart from improving the existing domestic dispute settlement mechanisms for foreign-related disputes. For investor-state disputes, China should also conclude more bilateral investment treaties with 
other BR countries.

\section{B. Facilitation of a Bilateral Dispute Settlement Mechanism between China and Other BR Countries}

As of July 16, 2018, there were only 17 effective bilateral judicial assistance treaties for civil and commercial matters between China and other countries, and only 19 effective bilateral judicial assistance treaties for civil, commercial and criminal matters. ${ }^{53}$ According to information from the PRC Ministry of Commerce, there are currently 104 bilateral investment treaties between China and other countries. ${ }^{54}$ Some of those countries that have received large sums of Chinese FDI have not concluded BITs with China yet.

Considering the great diversity among the legal systems of China and those of other BR countries, the PRC Ministry of Foreign Affairs (Department of the Treaty and Law) should actively initiate negotiations with more BR countries to conclude such treaties. These bilateral treaties provide a set of clear and uniform rules regarding ascertaining jurisdiction, the service of judicial and extrajudicial documents, the taking of evidence, the recognition and enforcement of foreign judgments, and the exchange of legal materials and information. Additionally, a monitoring mechanism should be set up to facilitate the smooth implementation of such treaties.

Meanwhile, considering the potential increase of investment disputes between Chinese investors and the governments of the BR countries due to China's increasing investment in these countries, the PRC Ministry of Commerce (Department of the Treaty and Law) may start negotiations with the BR countries that have not concluded bilateral investment treaties with China, so as to provide guarantees for Chinese investors against potential political, legal and expropriation risks. Based on such development, the China Council for the Promotion of International Trade may work with authorities in the BR countries for establishing a BR Joint Arbitration Center, aiming at drafting a multilateral arbitration convention. ${ }^{55}$

\section{Proposal to Build a Multilateral Dispute Settlement Mechanism among the BR countries}

For the resolution of civil, commercial and investment disputes with foreign 
elements, a multilateral channel will be more convenient and efficient in the long run. Thus, the PRC Ministry of Foreign Affairs (Department of the Treaty and Law) should actively participate in the negotiation and conclusion of multilateral treaties like the Hague Convention of 30 June 2005 on the Choice of Court Agreements in order to encourage other BR countries to join them. China should also strengthen cooperation in terms of litigation and arbitration with regional organizations such as the European Union, the Asia-Africa Legal Consultative Organization (AALCO), and the Organization of American States (OAS). These organizations have adopted many legal documents for common judicial cooperation. In this regard, China may consider starting negotiation with regional trade organizations such as the Southern African Development Community (SADC), the Common Market of Eastern and Southern African States (COMESA), the Greater Arab Free Trade Area (GAFTA), and the Southern American Common Market (MERCOSUR).

In the future, China should construct a legal framework, such as a BR Economic Partnership Agreement. Under such a framework, China and other BR countries could discuss or even conclude a regional convention on the resolution of civil, commercial and investment disputes with foreign elements in the BR region. It would promoting the free movement of goods, capital, services and labor among the BR countries.

\section{Conclusion}

Considering the BRI and the status quo of the dispute settlement mechanisms between China and other BR countries, the future BR dispute settlement mechanism should focus on improving China's legal framework for settling foreign-related civil, commercial and investment disputes, which leads the BR parties to choose China as an ideal place to settle their disputes. Meanwhile, China should consider negotiating and concluding more bilateral treaties in judicial cooperation and investment promotion and protection with other BR countries or regional organizations. Optimistically, China may propose the establishment of a unified multilateral dispute settlement mechanism among the BR countries. Or, it can preset the arbitration as the primary means for solving the dispute, leaving litigation 
as the secondary means, and mediation as a pre-procedure before arbitration or litigation. The International Commercial Courts in China manifested China's determination to improve its settlement mechanisms for foreign-related civil and commercial disputes. The jurisdiction of such courts, however, is limited in scope, and the relationship between litigation in such courts and arbitration or mediation is not clearly defined in the Supreme People's Court's Opinions. Whether China's courts will become a platform on which many countries decide to settle their BR disputes, or not, remains to be seen.

\section{REFERENCES}

1. See, e.g., Yongping Xiao, To Improve the International Public Credibility of China's Justice: the Key of Co-building the Belt and Road [提升中国司法的国际公信力: 共建一带一路的抓手], 1 Wuhan U. Int'L L. Rev. [武大国际法评论] 3 (2017); Jingdong Liu, Study on the Systematic Construction of the BR Legal System [一带一路法治体系化构建研究], 5 TRIBUnE OF PoliticaL SCI. \& L. [政法论坛] 125. (2017); The Construction of a Fair and Reasonable BR Dispute Settlement Mechanism [构建公正合理的一带一路争端解决机制], 5 PACIFIC J. [太平洋学报] 13 (2017); Beiping Chu, The Present and Future of the Construction of a Pluralized BR Dispute Settlement Center [一带一路多元争端解决中心构建的当下与未来], 6 CHINA LEGAL SCI. [中国法学] 72 (2017).

2. See The official website of the Belt and Road, available at https:/www.yidaiyilu.gov.cn/ xwzx/roll/45584.htm (last visited on Jan. 31, 2019).

3. Some Provisions on the Establishment of International Commercial Court [最高人民法院关于 建立国际商事法庭若干问题的规定], The Judicial Interpretation of the Supreme People's Court [2018] No.11 [法释[2018]11号] (effective as of July 1, 2018), available at http://www.court. gov.cn/fabu-xiangqing-104602.html (last visited on Jan. 31, 2019).

4. For a general understanding of the BRI, see National Development and Reform Commission, Visions and Actions on Jointly Building Silk Road Economic Belt and 21st Century Maritime Silk Road [推动共建丝绸之路经济带和 21 世纪海上丝绸之路的愿景与行动], available at http:// en.ndrc.gov.cn/newsrelease/201503/t20150330_669367.html (last visited on Jan. 31, 2019).

5. G.A. Res. 71/9, U.N. Doc. A/RES/71/9 (Nov. 17, 2016), available at http://www.un.org/zh/ documents/view_doc.asp?symbol=A/RES/71/9\&referer=http://www.un.org/zh/ga/71/res/all1. shtml\&Lang=E (last visited on Jan. 31, 2019).

6. From Idea to Action: the Great Achievements Made after Five Years of the BRI [从理念到行 动: 五年来一带一路建设取得这些重大进展], available at http://politics.gmw.cn/2018-08/28/ 
content_30837216.htm (last visited on Jan. 31, 2019).

7. Institute of World Economy and Politics of Chinese Academy of Social Sciences, Country Risk Report of Chinese Overseas Investment [中国海外投资国家风险级别报告] 32-3 (2016).

8. World Bank Group, Doing Business 2018: Reforming to Create Jobs, available at http:// www.doingbusiness.org/content/dam/doingBusiness/media/Annual-Reports/English/ DB2018-Full-Report.pdf (last visited on Jan. 31, 2019).

9. Id. at 4 .

10. Id. at 12-61.

11. Supra note 7 , at 5.

12. There is no official date of the actual loss of the Chinese enterprises during the Libyan war. The statistics here are available from BeIJng Bus. Today [北京商报], Apr. 25, 2011.

13. Ping An Life Insurance Company of China, Limited and Ping An Insurance (Group) Company of China, Limited v. Kingdom of Belgium, ICSID Case No. ARB/12/29 (Apr. 30, 2015), available at https://icsid.worldbank.org/en/Pages/cases/casedetail.aspx? $\mathrm{CaseNo}=\mathrm{ARB} / 12 / 29$ (last visited on Jan. 31, 2019).

14. Beijing Urban Construction Group Co. Ltd. v. Republic of Yemen, ICSID Case No. ARB/14/30 (June 7, 2018), available at https://icsid.worldbank.org/en/Pages/cases/ casedetail.aspx?CaseNo=ARB/14/30 (last visited on Jan. 31, 2019).

15. China Heilongjiang International Economic \& Technical Cooperative Corp., Beijing Shougang Mining Investment Company Ltd., and Qinhuangdaoshi Qinlong International Industrial Co. Ltd. v. Mongolia (Perm. Ct. Arb. 2017), available at https://pca-cpa.org/en/ cases/48 (last visited on Jan. 31, 2019).

16. The official website of China Referee Document Network [中国裁判文书网], available at http://www.wenshu.court.gov.cn (last visited on Jan. 31, 2019).

17. Vision and Action was issued on March 30, 2015 by China's National Development and Reform Commission, Ministry of Foreign Affairs and Ministry of Commerce with the authorization of China's State Council. See supra note 4.

18. President Xi Jinping's keynote speech delivered at the opening ceremony, Boao Asia Forum 2015, available at http:/www.xinhuanet.com/english/video/2015-03/28/c_134105149.htm (last visited on Jan. 31, 2019).

19. The Joint Communique, available at http://usa.chinadaily.com.cn/epaper/2017-05/16/ content_29367727.htm (last visited on Jan. 31, 2019).

20. Yaxin Shen, Tian Tian, Chenge Du, The Ten Key Words in President Xi Jinping's Serial Speeches during the Belt and Road Forum for International Cooperation [习近平 “一带一 路” 高峰论坛系列讲话十大高频词], available at http://politics.people.com.cn/n1/2017/0518/ c1001-29283687.html (last visited on Jan. 31, 2019).

21. Supra note 19.

22. Vision and Action Plan, pt. V (Cooperation Mechanism).

23. Id. 
24. Zhipeng He, China's Proposal for the International Rule of Law--BRI in the Global Governance Perspective [国际法治的中国方案- “一带一路” 的全球治理视角], 5 PAC. J. [太平 洋学报] 6 (2017).

25. The list of the 65 countries is unofficial, but now widely spread on the Internet. In the official Chinese documents, the BRI is open to all the nations in the world, and every nation may participate in it. According to the unofficial list, besides China, the other 64 BR countries are Afghanistan, Albania, Armenia, Azerbaijan, Bahrain, Bangladesh, Belarus, Bhutan, Bosnia and Herzegovina, Brunei, Bulgaria, Cambodia, Croatia, Czech Republic, Egypt, Estonia, Georgia, Greece, Hungary, India, Indonesia, Iran, Iraq, Israel, Jordan, Kazakhstan, Kuwait, Kyrgyzstan, Lao People's Democratic Republic, Latvia, Lebanon, Lithuania, The former Yugoslav Republic of Macedonia, Malaysia, Maldives, Republic of Moldova, Mongolia, Montenegro, Myanmar, Nepal, Oman, Pakistan, Philippines, Poland, Qatar, Romania, Russian Federation, Saudi Arabia, Serbia, Singapore, Slovakia, Slovenia, Sri Lanka, Syrian Arab Republic, Tajikistan, Thailand, Turkey, Turkmenistan, Ukraine, United Arab Emirates, Uzbekistan, Vietnam, Yemen, Palestine, and Cyprus.

26. They are Greece, India, Sri Lanka, Armenia, Turkey, Israel, Albania, Bosnia and Herzegovina, Bulgaria, Croatia, Estonia, Hungary, Latvia, Lithuania, Macedonia, Romania, Poland, Serbia, Slovakia, Slovenia, Russia, Belarus, Ukraine, Egypt, Cyprus, Pakistan, Czech, Kazakhstan, Montenegro and Kuwait. See the official website of The Hague Conference on Private International Law, available at https://www.hcch.net/en/instruments/conventions/ status-table/?cid=17 (last visited on Jan. 31, 2019).

27. They are India, Sri Lanka, Armenia, Turkey, Israel, Singapore, Albania, Bosnia and Herzegovina, Bulgaria, Croatia, Czech, Estonia, Hungary, Latvia, Lithuania, Macedonia, Romania, Poland, Serbia, Slovakia, Slovenia, Russia, Belarus, Ukraine, Greece, Cyprus, Kazakhstan, Montenegro and Kuwait. See the website of the Hague Conference on Private International Law, available at https://www.hcch.net/en/instruments/conventions/statustable/?cid=82 (last visited on Jan. 31, 2019).

28. The other 4 countries that are not members of the New York Convention are Maldives, Turkmenistan, Iraq and Yemen. See the website of the New York Convention, available at http://www.newyorkconvention.org/countries (last visited on Jan. 31, 2019).

29. The other 13 BR countries that have not ratified the Convention are Myanmar, Tailand, Laos, Vietnam, Iran, India, Pakistan, Maldives, Bhutan, Tajikstan, Kyrgyzstan, Russia and Poland. Russian and Kyrgyzstan have signed but not ratified the Convention. See ICISID, available at https://icsid.worldbank.org/en/Pages/about/Database-of-Member-States.aspx (last visited on Jan. 31, 2019).

30. They are Mongolia, Myanmar, Saudi Arabia, Qatar, Maldives, Turkmenistan, Montenegro, Greece, Cyprus, Malaysia, Philippines, India, Thailand, Singapore, Brunei, Bhutan, Cambodia, Bangladesh, Sri Lank, Iran, Georgia, Armenia, Azerbaijan, Turkey, Jordan, Bahrain, Oman, Bulgaria, Croatia, Estonia, Hungary, Lithuania, Macedonia, Poland, Serbia, 
Slovakia, Slovenia, Russia, Belarus, Ukraine, and Egypt. See UNCITRAL, available at http://www.uncitral.org/uncitral/en/uncitral_texts/arbitration/1985Model_arbitration_status. html (last visited on Jan. 31, 2019).

31. They are Bulgaria, Thailand, Hungary, Singapore, United Arab Emirates, Kuwait, Bosnia and Herzegovina. See PRC Ministry of Foreign Affairs (Department of the Treaty and Law), available at http://www.fmprc.gov.cn/web/ziliao_674904/tytj_674911/wgdwdjdsfhzty_ 674917/t1215630.shtml (last visited on Jan. 31, 2019).

32. They are Poland, Mongolia, Russia, Romania, Turkey, Ukraine, Belarus, Kazakhstan, Egypt, Greece, Cyprus, Kyrgyzstan, Tajikistan, Uzbekistan, Vietnam, Laos, and Lithuania. See id.

33. They are Albania, Armenia, Azerbaijan, Bahrain, Belarus, Bulgaria, Cambodia, Croatia, Czech Republic, Egypt, Estonia, Georgia, Greece, Hungary, India, Indonesia, Iran, Israel, Kazakhstan, Kuwait, Kyrgyzstan, Lao People's Democratic Republic, Lebanon, Lithuania, The former Yugoslav Republic of Macedonia, Malaysia, Republic of Moldova, Mongolia, Myanmar, Oman, Pakistan, Philippines, Poland, Qatar, Romania, Russian Federation, Saudi Arabia, Serbia, Singapore, Slovakia, Slovenia, Sri Lanka, Syrian Arab Republic, Tajikistan, Thailand, Turkey, Turkmenistan, Ukraine, United Arab Emirates, Uzbekistan, Vietnam, and Yemen. See PRC Ministry of Commerce (Department of the Treaty and Law), available at http://tfs.mofcom.gov.cn/article/Nocategory/201111/20111107819474.shtml (last visited on Jan. 31, 2019).

34. The 32 bilateral investment treaties were concluded between China and Czech Republic, Slovakia, Greece, Moldova, Albania, Croatia, Estonia, Slovenia, Lithuania, Serbia, Macedonia, Singapore, Kuwait, Sri Lanka, Malaysia, Turkey, Mongolia, Uzbekistan, Vietnam, Laos, Saudi Arabia, Azerbaijan, Indonesia, Oman, Lebanon, Cambodia, Syria, Qatar, Bahrain and Egypt.

35. The six bilateral investment treaties were concluded between China and Israel, Lithuania, Serbia, Macedonia, Bahrain and Saudi Arabia.

36. The eight bilateral investment treaties were concluded between China and Turkey, Uzbekistan, Russia, Malta, Iran, Myanmar, India and Cyprus.

37. The nine bilateral investment treaties were concluded between China and Turkey, Uzbekistan, Russia, Romania, Malta, Yemen, Myanmar, India and Cyprus.

38. See the Suzhou Consensus, available at http://www.sohu.com/a/73518080_117927 (last visited on Jan. 31, 2019).

39. Weidong Zhu, Determining the Validity of Arbitration Agreements in China: towards a New Approach, 6 Asian InT'L ARB. J. 62 (2010).

40. The Notice of the Supreme People's Court on Implementing the 1958 New York Convention [最高人民法院关于执行我国加入的<承认与执行外国仲裁裁决的纽约公约>的通知], Apr. 10, 1987 fa (jing)fa [1987] No.5 [法(经)发[1987] 5号].

41. Id.

42. The Supreme People's Court Judicial Interpretation on the Application of the Civil Procedural 
Law of the People's Republic of China [最高人民法院关于适用<中华人民共和国民事诉讼法> 的司法解释], Fashi [2015] No.5 [法释[2015] 5号].

43. Judicial Interpretation (2015), art. 533.

44. Id.

45. A. Lu Xu, China Cases Insight No. 3: Belt \& Road Typical Case 13: Towards a Liberal Interpretation of the Reciprocity Principle for Recognition and Enforcement of Foreign Judgments, Stanford Law School China Guiding Cases Project, June 29, 2018, available at https://cgc.law.stanford.edu/commentaries/clc-1-201806-insights-3-alison-xu (last visited on Jan. 31, 2019).

46. A Chinese court denied the recognition and enforcement of a judgment rendered by a Japanese court in 1994 on the ground that there is no reciprocity between China and Japan. In 2003 a Japanese court refused to recognize and enforce a Chinese court judgment on the same basis. Subsequently in 2004 a Chinese court denied again the recognition and enforcement of a Japanese court judgment and in 2015 a Japanese court also denied the recognition and enforcement of a Chinese court judgment on the non-existence of reciprocity between both sides. See generally Weidong Zhu, The Construction of the Negative Reciprocity System in the Recognition and Enforcement of Foreign Judgments China [试论我国承认与执行外国判决的反向互惠的构建], 4 HeBEI L. SCI. [河北法学] 19 (2017).

47. Zhu, id. at 24.

48. See The First and Second International Commercial Court were Set Up in Shenzen and Xi'an, Respectively [最高人民法院第一第二国际商事法庭分别在深圳、西安揭牌办公], PEOPLE’s DAILY [人民日报], June 30, 2018.

49. The Supreme People's Court's Provisions on the Establishment of the Belt and Road Dispute Settlement Mechanism and Institutions, art. 11.

50. Id. art. 2.

51. Article 34 provides that the parties to a contract or property interests dispute may choose in writing to submit their dispute to such courts that have actual connection with the dispute as the people's courts where the defendant or the plaintiff domiciles, where the contract is performed or concluded, where the subject matter locates, provided that the provisions of this Law regarding jurisdiction by forum level and exclusive jurisdiction are not violated.

52. The Supreme People's Court's Provisions on the Establishment of the Belt and Road Dispute Settlement Mechanism and Institutions, art. 11.

53. See The official website of the PRC Ministry of Foreign Affairs, available at http://www. fmprc.gov.cn/web/ziliao_674904/tytj_674911/wgdwdjdsfhzty_674917/t1215630.shtml (last visited on Jan. 31, 2019).

54. PRC Ministry of Commerce, Bilateral Investment Treaty [我国对外签订双边投资协定一览表], available at http://tfs.mofcom.gov.cn/article/Nocategory/201111/20111107819474.shtml (last visited on Jan. 31, 2019).

55. For example, with the increase of the civil and commercial disputes between China and 
African countries since the first Forum on the China-African Cooperation (FOCAC) was held in 2000, the author once proposed to set up a China-Africa Joint Arbitration Center as the platform to settle such disputes. See generally Weidong Zhu, Arbitration as the Best Option for the Settlement of China-African Trade and Investment Disputes 57 (1) J. Afr. L. 163 (2013). Later, the FOCAC Johannesburg Action Plan (2016-18) adopted at the Johannesburg Summit of the FOCAC on December 3-5, 2015 stated clearly that the two sides will work together "to establish a China-Africa Joint Arbitration Center." With the efforts made by both sides, the Johannesburg Center and the Shanghai Center of the ChinaAfrica Joint Arbitration Center were set up in November 2015. Subsequently, the Beijing Center, Shenzhen Center and Nairobi Center of the China-Africa Joint Arbitration Center were set up in March 2017. 